WOLFGANG MAENNIG

ENSURING GOOD GOVERNANCE AND PREVENTING CORRUPTION IN THE PLANNIG OF MAJOR SPORTING EVENTS - OPEN ISSUES

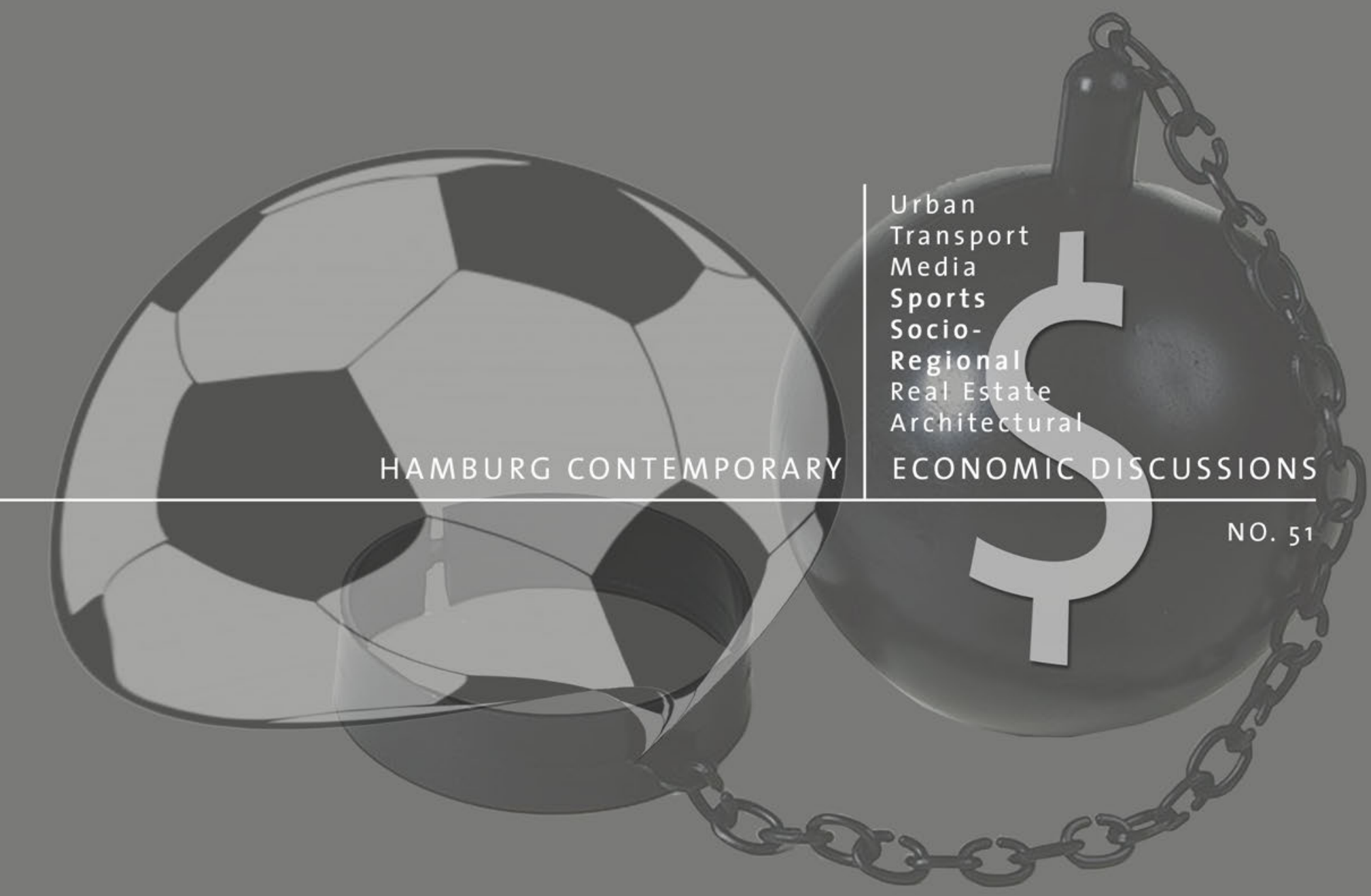


Hamburg Contemporary Economic Discussions

University of Hamburg

Faculty of Business, Economics and Social Sciences

Chair for Economic Policy

Von-Melle-Park 5

D-20146 Hamburg | Germany

Tel +49 $4042838-4622$

Fax $+494042838-6251$

http://www.uni-hamburg.de/economicpolicy/maennig.htm

Editor: Wolfgang Maennig

Wolfgang Maennig

University of Hamburg

Faculty of Business, Economics and Social Sciences

Chair for Economic Policy

Von-Melle-Park 5

20146 Hamburg | Germany

Tel +49 $4042838-4622$

$\mathrm{Fax}+494042838-6251$

wolfgang.maennig@wiso.uni-hamburg.de

ISSN 1865 - 2441 (Print)

ISSN 1865 - 7133 (Online)

ISBN 978-3-942820-16-5 (Print)

ISBN 978-3-942820-17-2 (Online) 
Wolfgang Maennig

\title{
Ensuring good governance and preventing corruption in the planning of major sporting events - open issues
}

\begin{abstract}
International sports will have to strengthen their efforts to exclude persons with morals in conflict with their sports. IOC and FIFA should mirror their top ambitions in athletic and financial areas by similarly leading ambitions to serve human mankind more generally. To encounter critiques that the organizing of major sporting events are „elitist actions" IOC and FIFA should declare ex-ante referenda as a precondition for bidding. In order to reduce the funds available for corruption, the role of public finance in major sporting events should be overthought. At least broadcasters under public law public should be excluded from the bidding for TV. FIFA and other sporting federations should make public their payments to member federations etc and the underlying decision criteria.
\end{abstract}

Keywords: Corruption, FIFA, good governance, major sporting events, referenda, public finance

JEL classification: $L 83$

Version: July 2015

Corruption in the planning of major events may start as early as during the bidding process - see the Salt Lake City 2002 Winter Olympic Bid. Some argue that it may even start earlier (see section "referenda" below). And corruption may not end with the opening of the event - see the gold medal decision in the 2002 Olympics figure skating competition in favour of the Russian skating duo and the verdict in the finals of the Olympic boxing competition in Seoul in 1988 against the super middleweight boxer Roy Jones. Corruption may target on host venues and the allocation of TV or marketing rights (ISL-scandal). Corruption affects almost all stages of the value creation chain, and in all groups of "stakeholders", including nominations for positions and commissioning of construction works for sports arenas and other venues. ${ }^{1}$

\footnotetext{
${ }^{1}$ For an overview up to $2004 \mathrm{cf}$. Maennig (2005). In recent years most cases of corruption in sports were betting-related, see SportAccord (2011) and Forrest and Maennig (2015).
} 


\section{Truly world-leading ambitions for international sporting institutions}

With the Olympic Games and the World Cup, IOC and FIFA do control the two most fascinating events of the world which attract the desire to host them in all parts of the world. These sporting institutions do have top ambitions (and positions) in athletic and financial areas that could and should be mirrored by similarly leading ambitions to serve human mankind more generally. In a sense, both institutions are in a truly unique position to change the world for the better, potentially more influential than any other institution or power in the world, including even that of USA, UNO, NATO etc. With much less efforts and resources then such institutions, FIFA and IOC could use their position to enforce standard requirements for good governance, labour regulations, minority protection, etc. by declaring them as a precondition for being eligible to bid or organise their events. Many nations with deficiencies in these areas would change their practices, just to be able to apply. Any counter-argument that IOC and FIFA do not have a general political mandate does not apply if IOC and FIFA do not develop their own standards, but use internationally agreed standards, developed by institutions like the ILO, WTO, etc. Another potential counter-argument may be that such standards are biased towards „todays' western values“, which were not fulfilled by western nations themselves some decades ago. It might be argued that such prescriptions imply a western hegemony, including e.g. religious arrogance and/or simply a protectionist attempt to hinder the competition from emerging regions. International standards should thus be checked as to whether they comprise some sort of a world-wide consensus, in order to ensure that they possess an inclusive character. Once this is done, IOC and FIFA should enforce internationally agreed standards of good governance which other institutions are unable to enforce. The time is ripe for such a more ambitious, truly world-leading self-awareness and self-esteem of these organisations.

\section{Referenda and participation as a formal prerequisite}

A leading critique is that the bidding for, and the organizing of major sporting events are „elitist actions“, serving the interest of a few (e.g. athletes, real estate owners, construction firms, politicians), harming the lives of many, and not serving the majority of the population. In almost all cases, the bidding and organising of major sporting 
events is accompanied by such criticism during the entire period up to the opening ceremony. These critiques almost always make accusations that corrupt behaviour is taking place, for example against political officials who - although obliged to serve the people - are accused of being misled by a few agents and taking decisions against the „real will“ of the majority. In rsponse, some of the cities thinking about bidding for Olympic Games have decided to hold referenda. With very few exceptions, until now, such referenda decided against holding the Olympics, reinforcing the critique of elitist corruption in the cases of bids without ex-ante referenda.

This general critique and the accompanying criticism of misallocation of public funds, disregard of otherwise established processes of participation, displacement of underpriviledged persons and other anti-social side effects regularily hinder the efficient planning and organising of the events. ${ }^{2}$ Furthermore, such critiques are endangering the positive image of the sporting federations. The violent protests in Brazil in 2013 should be regarded as a clear signal that successful major sporting events need to have the support of a broad majority of the population.

As a far-reaching mechanism to counter the the allegation of elitist corruption, and starting from the belief that major sporting events are attractive events that may well convince the majority, IOC, FIFA and other sporting institutions could declare ex-ante referenda or other participation processes appropriately adapted to the nation's normal practices as a precondition for bidding. This will prolong the time period required for the process from the current (at least) ten years by some two to three additional years at minimum. The resulting longer period of ante-bidding preparation may well fit within the increased ambitions of e.g. Olympic Games organisers which regularly (mis?)interpret the Games as a tool for urban regeneration - which is hardly feasible within some 10 years in multi-layered societies with well-ordered check and balances.

Ante-bidding referenda imply the risk of having fewer bidding cities/nations. On the positive side, the quality of the bids will increase. Interested cities/nations will need to invest more resources into developing bidding concepts that convince their own

\footnotetext{
${ }^{2}$ For the (critique of the) planning displacement see Porter et al (2009), for the other critical aspects in the case of Brazil 2014/2016 see Aragão and Maennig (forthcoming).
} 
populations (and, consequently the deciding bodies in the sporting federations). Having the majority in support, the organising will afterwards be smoother. It may happen that more effort will be saved during the bidding and organising period than is invested in the ante-bidding period.

Such „convincing“ should not be regarded as one-way street: the people's participation and inclusion of the views of all milieus of society on urban development may well increase the perceived quality of the concepts. Especially in the case of urban development, the competences of the formal elites in politics and administration are no longer accepted as superior within a growing number of social milieus.

The ideas that come out of such participation processes may well reveal some painful pieces of information with regard to the weak points of major sporting events. For example, there may be requests to plan Olympic facilities in a way that makes them available inclusively for "sports for all" after the event. Compensating measures may not be asked for, not only in the ecological sphere, but also in social respects, for example in order to address the fear of increasing rents and real estate prices felt by many persons. In the end, dealing with such requests may strengthen the bidding concepts for major sporting events.

\section{Overthinking the role of public finance in major sporting events}

There may even be demands for a private financing of such major sporting events, so as not to put further stress on public finances. When referring to the above interpretation of corruption as an intentional choice, such demands may make additional sense: the danger of corruption generally increases if sufficiently large payments to potentially corrupt individuals can be financed. It is no wonder that the events of those sports that are able to generate considerable sources of pecuniary income, such as football, boxing, and basketball, have historically been most affected by corruption. An obvious solution, to take money out of sports, is hardly feasible, but also economically inefficient (Maennig, 2002).

Nevertheless, it is quite obvious, that some of the recent corruption scandals would not have happened if no or less public money had been involved. The significantly increasing budgets for World Cups and Olympic Games over recent decades, which - 
including urban infrastructure - now easily reach double-digit US\$ billion (Zimbalist, 2015) have provided a potential additional impulse for corruption. With complete private financing and no public funds, there would be much less investment for sport facilities and other infrastructure - severely limiting the scope for corruption. Los Angeles 1984 and Atlanta 1996 were able to organise the Games without or near to zero public finance, and these two showcases should be scrutinised by other bidding nations. By the way, such a method of financing would bring the Games much closer to its roots as a sporting event, rather than an occasion for urban regeneration.

If „no public finances“ for major sporting events appears too far reaching as an objective, the principle should at least be implemented for broadcasters and other institutions under public law public, which in many parts of the world induced a sharp but finally unfair competiton, resulting in a sharp increase in the TV and marketing revenues of major sporting events. Of course, such a policy initiative will not be actively promoted by international sports. But with a worldwide consensus of public authorities to exclude institutions under public law public from the bidding for TV and marketing rights, the available funds and thus the risk of corruption should be reduced. ${ }^{3}$

\section{Host selection: Selecting a pool of future host of Olympic Games and World Cups}

The time period between the selection of a host of the Olympic Games or the World Cup and the opening ceremony appear to be too short for many cities/countries, at least as long as they interpret the events as a tool for urban re-generation. It is sometimes argued that the time pressure is a major source of cost increases and corruption because decision makers do not have much choice. As a response, $I O C$ and FIFA could change their selection modus. Instead of selec-ting of one city (country) seven (six) years ahead of the Olympic Games (World Cup), the institutions could select a pool of some three to four future hosts. The final decision/determination of the host will take place some four years ahead of the event, based on the current status of the preparation. After each final determination of the next host, a new future host would be added to the pool. Such a mechanism would have the advantage that the host may

\footnotetext{
${ }^{3}$ Free TV could nevertheless be prerequisite.
} 
make use of different speeds of preparation, but not hindering investments, as there is the certainity to be the host in the near future.

\section{Human resources: selection, rotation, limitation, payment and accountability}

Today, participation in many societies is equated with freedom, and sometimes paralleled in importance to equality before the law and to equal opportunity. This principle should be included in all steps of the decision-making, also - and especially in the process of finding the leadership for the bidding or organising team. Up to now, in almost all cases, the selection process was limited to a small circle of decision makers in a non-transparent process. In too many cases the selection process led to the enthroning of politically exposed who „represent a greater degree of risk of corruption“ (UNODC, 2013, p. 19). Furthermore, there are very few (any?) known cases of bids/organisation processes of major sporting events known where the leading persons did not have to be removed after a certain time. From a historical perspective and in general, the selection processes of leadership personnel for major sporting events cannot be regarded as successful. A selection which includes a public participation process may well increase the quality (and acceptance) of the leadership team. Such a selection process may well conclude with the decision not to install a single "head“, but rather a team of peers with different abilities, specialisations and backgrounds - a well established everyday athletic principle in almost all sports.

Regarding the payment of the officials - and notwithstanding the above reasoning for reducing the budgets of sporting events by excluding public finance - it could be useful to consider higher payments for the officials. Historically, in many cases the corrupted persons came from less privileged regions or felt under-priviledged in relation to their peers. This may imply a need to change the human resource concept for officials in institutions like IOC and FIFA to a system of significantly higher incomes compared to today's situation. Officials should be paid an allowance that is higher than the standard market wage for equivalent activities („efficiency wages“). The perceived risk of losing such an income would decrease the corruptlbilty of sporting officials. Taken one step further, a deferred compensation model (Lazear, 1979; Maennig, 2002) should be constructed, i.e., a large part of the income of the officials would have to be paid into (pension) funds which would then be paid out after end of a corruption-free 
sporting career. The system would be similar to the relatively high payment of, for example judges in many societies, preventing the corruption of these officials. Indeed, salaries of high-ranking judges could be a good minimum starting point for top sporting officials, even adjusted for a shorter duration of holding the job and of being able to accumulate wealth.

Finally some other measures should be mentioned: other sporting institutions should analyse the IOC limitation of terms of office, eventually accompanied by job/office rotation which may be meaningful measures against corruption because they prevent a too high level of trust between potential providers and recipients of bribes. Also, even in the case of public finances for the major sporting events, the case of the Governor of the Reserve Bank of New Zealand whose contract was to be prolonged exclusively if certain inflation rates are not exceeded may be analysed.

\section{Transparency as a balancing tool between algorithmics and politics}

In 2015, the member federations received from FIFA

„a standard $\$ 250,000$ annual grant as well as a one-time $\$ 500,000$ bonus from profits linked to the 2014 World Cup. Associations can also apply for FIFA Goal Programme money, for projects such as soccer fields and offices, and financial aid for specific construction or outreach programs. FIFA is also dispensing one-time bonuses in the millions to regional soccer confederations." (N.N., 2015)

Most of the current allegations of corruption against FIFA argue that these payments are dicretionary, ad-hoc, hardly tracable, but nevertheless systematic by maximising the number of votes for certain elections and decisions by positively discriminating in favour of the many smaller and poorer member federations.

Strict anti-corruption ideas could call for a formula that - for example - defines a fixed sum for each member plus a variable payment according to membership numbers, athletic performance at World Cups and the like. FIFA would be bound to a zero discretion, comparable to the odyssian approach of prevention against the temptation of the sirens. 
Beside the possibility to redefine the algorithm from time to time, such an approach would imply the end of (sport) politics in the sense of its usual interpretation as a decision-based social process based on a possibly time-varying weighting of the relative importance of different targets and criteria. Algorithms are intrinsically backward-looking, leaving less room for politics in the sense of a future-oriented strategy. For example, it could be argued by less priviledged FIFA member countries that an algorithm that is based on the past athletic performance will cement a historically grown hegemony of some few priviledged nations.

In principle, the known FIFA payment structures, favouring poorer members, resemble those of other (sporting) institutions which nevertheless do not suffer from allegations of corruption. One of the major differences between FIFA and other federations lies in the degree of traceability of their payments to its members. FIFA and other sporting federations should make public their payments and the underlying decision criteria. Such a strategy of transparency will not calm all allegations of unfair or biased financial policies, but will help to find a balance between algorithmics and politics.

\section{Literature}

ALM, J. (ed.) (2013), Action for Good Governance in International Sports Organisations. Copenhagen: Play the Game/Danish Institute for Sports Studies.

ANDREWS, M. (2010), Good Government Means Different Things in Different Countries. Governance: An International Journal of Policy, Administration, and Institutions 23, 7-35.

ANECHIARICO, F. / JACOBS, J. B. (1996), The pursuit of absolute integrity: How corruption control makes government ineffective. Chicago: University of Chicago Press.

ARAGÃO, T. / MAENNIG, W. (forthcoming), Mega sporting events, real estate, and urban social economics. The case of Brazil 2014/2016. In P. Esteves et al. (eds), BRICS and Mega-Sporting events. Rio de Janeiro: BRICs Policy Center at PUC-Rio.

AUSTRALIAN SPORTS COMMISSION (2012), Sports Governance Principles, www.ausport.gov.au/_data/assets/file/0010/485857/ASC_Governance_Principles.pdf.

BALOYI, L. / BEKKER, M. (2011), Causes of construction cost and time overruns: The 2010 FIFA World Cup Stadia in South Africa. Acta Structilia 18, 51-67.

CHAPPELET, J-L. / MRKONJIC, M. (2013), Basic Indicators for Better Governance in International Sport (BIBGIS): An assessment Tool for international sport governing bodies, www.transparency.ch/de/PDF_files/Newsletter/201306_Newsletter_Publikation_Chappelet_ und_Mrkonjic_2013_Basic_Indicators_for_Better_Governance_in_International_Sport.pdf. 
COMMISSION OF THE EUROPEAN COMMUNITIES (2007), WHITE PAPER ON SPORT, 11.07.2007, eur-lex.europa.eu/legal-content/EN/TXT/?qid=1389190214279\&uri=CELEX:52007DC0391.

COUNCIL OF THE REPRESENTATIVES OF THE GOVERNMENTS OF THE MEMBER STATES (2011), Resolution on a European Union Work Plan for Sport for 2011-2014, Official Journal of the European Union, 01.06.2011, eur-lex.europa.eu/legal-content/EN/TXT/PDF/?uri=CELEX: 42011Y0601(01)\&from $=E N$.

EUROPEAN COMMISSION (2011), COMMUNICATION FROM THE COMMISSION TO THE EUROPEAN PARLIAMENT, THE COUNCIL, THE EUROPEAN ECONOMIC AND SOCIAL COMMITTEE AND THE COMMITTEE OF THE REGIONS. Developing the European Dimension in Sport, 18.01.2011, eur-lex.europa.eu/legal-content/EN/TXT/?qid=1389190399614\&uri=CELEX: $52011 D C 0012$.

EUROPEAN UNION EXPERT GROUP „GOOD GOVERNANCE“ (2013), Principles of good governance in sport, EU Work Plan for Sport 2011-2014, September 2013, ec.europa.eu/sport/library/policy_documents/xg-gg-201307-dlvrbl2-sept2013.pdf.

FORREST, D. / MAENNIG, W. (2015), The Threat to Sports and Sports Governance from Bettingrelated Corruption: Causes and Solutions. In P. M. Heywood (ed.), Routledge Handbook of Political Corruption (pp. 328-346). London, New York: Routledge Taylor and Francis Group.

GEERAERT, A. et al. (2013), Good governance in international sport organisations. An analysis of the 35 Olympic Sport Governing Bodies. International Journal of Sport Policy and Politics 6, 281306.

GOVERNMENT OF SOUTH AUSTRALIA, Sports Governance Principles: A Good Practice Guide, www.ors.sa.gov.au/_data/assets/file/0004/145795/Sports-Governance-Principles-A-GoodPractice-Guide.pdf.

INTERNATIONAL OLYMPIC COMMITTEE (2008), Basic Universal Principles of Good Governance of the Olympic and Sports Movement, Seminar on Autonomy of Olympic and Sport Movement, 11-12 February 2008, www.olympic.org/Documents/Conferences_Forums_and_Events/ 2008_seminar_autonomy/Basic_Universal_Principles_of_Good_Governance.pdf.

IOC-FIFA (2007), Joint Declaration - EU white paper on sport: Much work remains to be done, 11.07.2007, www.olympic.org/content/news/media-resources/manual-news/1999-2009/ 2007/07/11/ioc-fifa-joint-declaration---eu-white-paper-on-sport-much-work-remains-to-bedone/.

KATZ, A. / KHAN, A. / STANFORD, D. (2015), A league of his own, http://www.bloomberg.com/ graphics/2015-sepp-blatter-fifa/.

LAZEAR, E. P. (1979), Why is there mandatory retirement? Journal of Political Economy 87, 1261-1284.

LEOPKEY, B. / PARENT, M. M. (2009), Risk Management Issues in Large-Scale Sporting Events: A Stakeholder Perspective. European Sport Management Quarterly 9, 187-208.

MAENNIG, W. (2002), On the economics of doping and corruption in international sports. Journal of Sports Economics, February, 61-89.

MAENNIG, W. (2005), Corruption in International Sports and Sport Management: Forms, Tendencies, Extent and Countermeasures. European Sport Management Quarterly 2, 187-225. 
MAENNIG, W. / ZIMBALIST, A. (2012) (eds.), International Handbook on the Economics of Mega Sporting Events. Cheltenham, Northampton: Edward Elgar Publishing.

PIETH, M. (2011), Governing FIFA, Concept paper and report. Basel: Universität Basel.

PIELKE, R. (2013), How can FIFA be held accountable? Sport Management Review 16, 255-267.

PLAY THE GAME/DANISH INSTITUTE FOR SPORTS STUDIES (2013), Action for Good Governance in International Sports Organisations, Final report.

PORTER, L. et al. (2009), Planning Displacement: The Real Legacy of Major Sporting Events. Planning Theory \& Practice 10, 395-418.

PRESTON, I. / SZYMANSKI, S. (2003), Cheating in Contests. Oxford Review of Economic Policy 19, 612-624.

SIRC, Principles of Good Government, sirc.ca/resources/sport-governance-andleadership/chapter-1-principles-good-governance.

SPORTACCORD (2011), Integrity in Sport. Understanding and Preventing Match-Fixing. Moudon.

SPORT AND RECREATION ALLIANCE, VOLUNTARY CODE OF GOOD GOVERNANCE FOR THE SPORT AND RECREATION SECTOR, www.sportandrecreation.org.uk/sites/ sportand recreation. org.uk/files/web/GovernanceCodeFINAL.PDF_.easyprint\%20Version.pdf.

SPORT TASMAN, SportAssist Activity Booklet Event Planning \& Management, www.tasmanregionalsports.org.nz/webfm_send/671.

SUGDEN, J. / TOMLINSON, A. (1998), FIFA and the contest for world football: Who rules the peoples' game? Cambridge: Polity Press.

TRANSPARENCY INTERNATIONAL (2009), Corruption and Sport: Building Integrity and Preventing Abuses. Berlin: Transparency International.

UNODC (2013), A Strategy for Safeguarding against Corruption in Major Public Events, www.unodc.org/documents/corruption/Publications/2013/13-84527_Ebook.pdf.

VAN DOEVEREN, V. (2011), Rethinking Good Governance: Identifying Common Principles. Public Integrity 13, 301-318.

WOODS, N. (1999), Good Governance in International Organizations. Global Governance 5, 3961.

WORLD BANK (1994), Governance: The World Bank's Experience. Washington, D.C.: World Bank publications.

WORLD BANK (2003), Toolkit: developing corporate governance codes of best practice. Washington, D.C.: World Bank.

ZIMBALIST, A. (2015), Circus Maximus: The Economic Gamble Behind Hosting the Olympics and the World Cup. Washington, D.C.: Brookings Institutions Press. 


\section{Hamburg Contemporary Economic Discussions}

(Download: http://www.uni-hamburg.de/economicpolicy/hced.html)

51

50

49

48

47

46

45

44

43

42

40

39

38

MAENNIG, W.: Ensuring Good Governance and Preventing Corruption in the Planning of Major Sporting Events - Open Issues, 2015.

MAENNIG, W. / VIERHAUS, C.: Who Wins Olympic Bids? 2015 (2 version).

AHLFELDT, G. M. / MAENNIG, W. / RICHTER, F.: Urban Renewal after the Berlin Wall, 2013.

BRANDT, S. / MAENNIG, W. / RICHTER, F.: Do Places of Worship Affect Housing Prices? Evidence from Germany, 2013.

ARAGÃO, T. / MAENNIG, W.: Mega Sporting Events, Real Estate, and Urban Social Economics - The Case of Brazil 2014/2016, 2013.

MAENNIG, W. / STEENBECK, M. / WILHELM, M.: Rhythms and Cycles in Happiness, 2013.

RICHTER, F. / STEENBECK, M. / WILHELM, M.: The Fukushima Accident and Policy Implications: Notes on Public Perception in Germany, 2014 ( $2^{\text {nd }}$ version).

MAENNIG, W.: London 2012 - das Ende des Mythos vom erfolgreichen Sportsoldaten, 2012.

MAENNIG, W. / WELLBROCK, C.: London 2012 - Medal Projection Medaillenvorausberechnung, 2012.

MAENNIG, W. / RICHTER, F.: Exports and Olympic Games: Is there a Signal Effect? 2012.

MAENNIG, W. / WILHELM, M.: Becoming (Un)employed and Life Satisfaction: Asymmetric Effects and Potential Omitted Variable Bias in Empirical Happiness Studies, 2011.

MAENNIG, W.: Monument Protection and Zoning in Germany: Regulations and Public Support from an International Perspective, 2011.

BRANDT, S. / MAENNIG, W.: Perceived Externalities of Cell Phone Base Stations - The Case of Property Prices in Hamburg, Germany, 2011.

MAENNIG, W. / STOBERNACK, M.: Do Men Slow Down Faster than Women? 2010. 


\section{Hamburg Contemporary Economic Discussions}

(Download: http://www.uni-hamburg.de/economicpolicy/hced.html)

37

36
DU PLESSIS, S. A. / MAENNIG, W.: The 2010 World Cup High-frequency Data Economics: Effects on International Awareness and (Selfdefeating) Tourism, 2010.

BISCHOFF, O.: Explaining Regional Variation in Equilibrium Real Estate Prices and Income, 2010.

FEDDERSEN, A. / MAENNIG, W.: Mega-Events and Sectoral Employment: The Case of the 1996 Olympic Games, 2010.

FISCHER, J.A.V. / SOUSA-POZA, A.: The Impact of Institutions on Firms Rejuvenation Policies: Early Retirement with Severance Pay versus Simple Lay-Off. A Cross-European Analysis, 2010.

FEDDERSEN, A. / MAENNIG, W.: Sectoral Labor Market Effects of the 2006 FIFA World Cup, 2010.

AHLFELDT, G.: Blessing or Curse? Appreciation, Amenities, and Resistance around the Berlin "Mediaspree”, 2010.

FALCH, T. / FISCHER, J.A.V.: Public Sector Decentralization and School Performance: International Evidence, 2010.

AHLFELDT, G. / MAENNIG, W. / ÖLSCHLÄGER, M.: Lifestyles and Preferences for (Public) Goods: Professional Football in Munich, 2009.

FEDDERSEN, A. / JACOBSEN, S. / MAENNIG, W.: Sports Heroes and Mass Sports Participation - The (Double) Paradox of the "German Tennis Boom", 2009.

AHLFELDT, G. / MAENNIG, W. / OSTERHEIDER, T.: Regional and Sectoral Effects of a Common Monetary Policy: Evidence from Euro Referenda in Denmark and Sweden, 2009.

BJØRNSKOV, C. / DREHER, A. / FISCHER, J.A.V. / SCHNELLENBACH, J.: On the Relation Between Income Inequality and Happiness: Do Fairness Perceptions Matter? 2009.

AHLFELDT, G. / MAENNIG, W.: Impact of Non-Smoking Ordinances on Hospitality Revenues: The Case of Germany, 2009.

FEDDERSEN, A. / MAENNIG, W.: Wage and Employment Effects of the Olympic Games in Atlanta 1996 Reconsidered, 2009. 


\section{Hamburg Contemporary Economic Discussions}

(Download: http://www.uni-hamburg.de/economicpolicy/hced.html)

AHLFELDT, G. / FRANKE, B. / MAENNIG, W.: Terrorism and the Regional and Religious Risk Perception of Foreigners: The Case of German Tourists, 2009.

AHLFELDT, G. / WENDLAND, N.: Fifty Years of Urban Accessibility: The Impact of Urban Railway Network on the Land Gradient in Industrializing Berlin, 2008.

AHLFELDT, G. / FEDDERSEN, A.: Determinants of Spatial Weights in Spatial Wage Equations: A Sensitivity Analysis, 2008.

MAENNIG, W. / ALLMERS, S.: South Africa 2010: Economic Scope and Limits, 2008.

MAENNIG, W. / WELLBROCK, C.-M.: Sozio-ökonomische Schätzungen Olympischer Medaillengewinne: Analyse-, Prognose- und Benchmarkmöglichkeiten, 2008.

AHLFELDT, G.: The Train has Left the Station: Real Estate Price Effects of Mainline Realignment in Berlin, 2008.

MAENNIG, W. / PORSCHE, M.: The Feel-good Effect at Mega Sport Events - Recommendations for Public and Private Administration Informed by the Experience of the FIFA World Cup 2006, 2008.

AHLFELDT, G. / MAENNIG, W.: Monumental Protection: Internal and External Price Effects, 2008.

FEDDERSEN, A. / GRÖTZINGER, A. / MAENNIG, W.: New Stadia and Regional Economic Development - Evidence from FIFA World Cup 2006 Stadia, 2008.

AHLFELDT, G. / FEDDERSEN, A.: Geography of a Sports Metropolis, 2007.

FEDDERSEN, A. / MAENNIG, W.: Arenas vs. Multifunctional Stadia Which Do Spectators Prefer? 2007.

AHLFELDT, G.: A New Central Station for a Unified City: Predicting Impact on Property Prices for Urban Railway Network Extension, 2007.

AHLFELDT, G.: If Alonso was Right: Accessibility as Determinant for Attractiveness of Urban Location, 2007.

AHLFELDT, G., MAENNIG, W.: Assessing External Effects of City Airports: Land Values in Berlin, 2007. 


\section{Hamburg Contemporary Economic Discussions}

(Download: http://www.uni-hamburg.de/economicpolicy/hced.html)

10

09

08

07

06

05

04

03

02

01

$04 / 2006$

$03 / 2006$

$02 / 2006$
MAENNIG, W.: One Year Later: A Re-Appraisal of the Economics of the 2006 Soccer World Cup, 2007.

HAGN, F. / MAENNIG, W.: Employment Effects of the World Cup 1974 in Germany.

HAGN, F. / MAENNIG W.: Labour Market Effects of the 2006 Soccer World Cup in Germany, 2007.

JASMAND, S. / MAENNIG, W.: Regional Income and Employment Effects of the 1972 Munich Olympic Summer Games, 2007.

DUST, L. / MAENNIG, W.: Shrinking and Growing Metropolitan Areas Asymmetric Real Estate Price Reactions? The Case of German Singlefamily Houses, 2007.

HEYNE, M. / MAENNIG, W. / SUESSMUTH, B.: Mega-sporting Events as Experience Goods, 2007.

DU PLESSIS, S. / MAENNIG, W.: World Cup 2010: South African Economic Perspectives and Policy Challenges Informed by the Experience of Germany 2006, 2007.

AHLFELDT, G. / MAENNIG, W.: The Impact of Sports Arenas on Land Values: Evidence from Berlin, 2007.

FEDDERSEN, A. / MAENNIG, W. / ZIMMERMANN, P.: How to Win the Olympic Games - The Empirics of Key Success Factors of Olympic Bids, 2007.

AHLFELDT, G. / MAENNIG, W.: The Role of Architecture on Urban Revitalization: The Case of "Olympic Arenas" in Berlin-Prenzlauer Berg, 2007.

MAENNIG, W. / SCHWARTHOFF, F.: Stadium Architecture and Regional Economic Development: International Experience and the Plans of Durban, October 2006.

FEDDERSEN, A. / VÖPEL, H.: Staatliche Hilfen für Profifußballclubs in finanziellen Notlagen? - Die Kommunen im Konflikt zwischen Imageeffekten und Moral-Hazard-Problemen, September 2006.

FEDDERSEN, A.: Measuring Between-season Competitive Balance with Markov Chains, July 2006. 


\section{Hamburg Contemporary Economic Discussions}

(Download: http://www.uni-hamburg.de/economicpolicy/hced.html)

01/2006 FEDDERSEN, A.: Economic Consequences of the UEFA Champions League for National Championships - The Case of Germany, May 2006.

04/2005 BUETTNER, N. / MAENNIG, W. / MENSSEN, M.: Zur Ableitung einfacher Multiplikatoren für die Planung von Infrastrukturkosten anhand der Aufwendungen für Sportstätten - eine Untersuchung anhand der Fußball-WM 2006, May 2005.

03/2005 SIEVERS, T.: A Vector-based Approach to Modeling Knowledge in Economics, February 2005.

02/2005 SIEVERS, T.: Information-driven Clustering - An Alternative to the Knowledge Spillover Story, February 2005.

01/2005 FEDDERSEN, A. / MAENNIG, W.: Trends in Competitive Balance: Is there Evidence for Growing Imbalance in Professional Sport Leagues? January 2005. 
